Article

\title{
Biomass and Lipid Production Potential of an Indian Marine Algal Isolate Tetraselmis striata BBRR1
}

\author{
Annakkili Baskara Boopathy 1,2,3, Thanasekaran Jayakumar ${ }^{3}$, Senthil Chinnasamy ${ }^{4}$ (D), \\ Muthu Ganesan Rajaram ${ }^{1}$, Natarajan Mohan ${ }^{1}$, Subramani Nagaraj ${ }^{1} \oplus$, Ramasamy Rengasamy ${ }^{1}$, \\ Manjunath Manubolu $\left.{ }^{5}{ }^{(}\right)$, Joen-Rong Sheu ${ }^{3,6, *}$ - and Chao-Chien Chang ${ }^{6,7,8, *}$ \\ 1 Centre for Advanced Studies in Botany, University of Madras, Guindy Campus, Chennai, \\ Tamil Nadu 600025, India; annakkilibaskar@gmail.com (A.B.B.); raja.ram091@gmail.com (M.G.R.); \\ jnmohan08@gmail.com (N.M.); nagalilly@gmail.com (S.N.); profrrengasamy@yahoo.com (R.R.) \\ 2 Department of Biochemistry, Caussanel College of Arts and Science, Muthupettai, Ramanathapuram, \\ Tamil Nadu 623523, India \\ 3 Graduate Institute of Medical Sciences, Taipei Medical University, Taipei 11031, Taiwan; \\ jayakumar@tmu.edu.tw \\ 4 Biotechnology Division, Aban Infrastructure Private Limited, Chennai, Tamil Nadu 600008, India; \\ senthilc@aban.com \\ 5 Department of Evolution, Ecology and Organismal Biology, Ohio State University, Columbus, OH 43212, \\ USA; manubolu.1@osu.edu \\ 6 Department of Pharmacology, School of Medicine, College of Medicine, Taipei Medical University, \\ Taipei 11031, Taiwan \\ 7 Division of Cardiology, Department of Internal Medicine, School of Medicine, College of Medicine, \\ Fu Jen Catholic University, New Taipei City 24205, Taiwan \\ 8 Department of Cardiovascular Center, Cathay General Hospital, Taipei 10630, Taiwan \\ * Correspondence: sheujr@tmu.edu.tw (J.-R.S.); change@seed.net.tw (C.-C.C.); \\ Tel.: +886-2-2736-1661-3199 (J.-R.S); +886-2-2708-2121-3116 (C.-C.C.)
}

Received: 17 December 2019; Accepted: 7 January 2020; Published: 10 January 2020

Abstract: Four different strains of marine algae viz. Tetraselmis tetrathele, Tetraselmis striata, Tetraselmis chuii, and Tetraselmis gracilis were isolated from the saltpans in Kovelong, Chennai, Tamil Nadu, India. The systematic position of Tetraselmis striata BBRR1 was confirmed through molecular identification. Under laboratory conditions, T. striata Butcher BBRR1 grown in $\mathrm{f} / 2$-medium recorded highest biomass concentration of $0.58 \pm 0.021 \mathrm{~g} \mathrm{~L}^{-1}$, volumetric productivity of $0.025 \pm 0.004 \mathrm{~g} \mathrm{~L}^{-1} \mathrm{~d}^{-1}, 19 \pm 2.3 \%$ proteins, $17 \pm 1.5 \%$ carbohydrates, and $15 \pm 2.4 \%$ lipids. Volumetric biomass productivity of $0.063 \pm 0.08 \mathrm{~g} \mathrm{~L}^{-1} \mathrm{~d}^{-1}$, specific growth rate of 0.45 day $^{-1}$ and lipid content of $19.42 \pm 0.98 \%$ were recorded for the alga T. striata Butcher BBRR1 cultivated in 10- $\mathrm{m}^{2}$ open raceway ponds using Modified CFTRI ABRR1 medium. The fatty acid profile of T. striata Butcher BBRR1 showed the presence of $33.14 \%$ palmitic acid, $22.64 \%$ 11-octadecenoic acid, and $21.94 \%$ heptadecanoic acid. This study confirms the feasibility of cultivating the marine alga T. striata in open raceway ponds to produce biomass, which can be used for the production of biofuels.

Keywords: biomass; bioenergy; carotenoids; green algae; lipids; Tetraselmis striata; raceway ponds

\section{Introduction}

Fossil-based energy is one of the most needed factors for development and economic growth. The use of fossil fuel sources for transport and energy applications is increasing day by day, which has a negative impact on the environment. Developing countries like India and China are heavily dependent on fossil fuels for their growth, and India imports $87 \%$ of its total petroleum crude requirement from 
oil-producing countries. In order to ensure energy security, majority of the countries are now looking for alternative sources of renewable liquid transportation fuels. First-generation biofuels derived from food crops are not sustainable. Second-generation biofuels such as $2 \mathrm{G}$ ethanol require vast amounts of biomass sources as feedstock. Recently, microalgae have gained importance as they can provide a sustainable source of biomass to produce biofuels. Biomass productivity and photosynthetic efficiency of microalgae are much higher than that of terrestrial crops, and microalgae are also rich sources of lipids, proteins, carbohydrates, pigments, and other value-added bioactive compounds $[1,2]$. Microalgae are capable of accumulating substantial amounts of triglycerides up to 50\% of dry cell weight. Microalgae can also grow in saline, brackish, and poor-quality wastewaters [3]. Microalgae are considered as potential sources of feedstock for biofuels as they only need non-arable land, poor-quality waters including seawater, brackish water, and waste water, and $\mathrm{CO}_{2}$ from flue gas for their growth [4].

Advanced and promising methodologies are continuously improving microalgae cultivation to overcome problems in biomass production for various applications [5]. Microalgae can be cultivated on non-arable and unproductive lands using seawater [6]. Many strains of microalgae are exceedingly rich in oil, which is a major source for biodiesel production [7]. Microalgae are traditionally considered as good source of fatty acids [3], which are suitable for biofuel production [8]. The fatty acid profiles of microalgae have been well established $[9,10]$. The aim of this study was to cultivate the alga Tetraselmis striata isolated from saltpans in an open raceway pond and evaluate its growth performance in terms of biomass and lipids.

\section{Materials and Methods}

\subsection{Isolation of Algal Strains}

Water samples were collected from saltpans of Kovelong $\left(12.7870^{\circ} \mathrm{N}, 80.2504^{\circ} \mathrm{E}\right)$, Chennai, Tamil Nadu, India. Water samples were enriched with $\mathrm{f} / 2$-nutrient medium to promote the growth of algal cells. Enriched water samples were then subjected to serial dilution and plated on $\mathrm{f} / 2$-agar medium [11]. Single colonies of different isolates were picked up using a micropipette. The isolates were then inoculated in the $\mathrm{f} / 2$-growth medium. To $950 \mathrm{~mL}$ of filtered natural seawater, the following ingredients were added, and the final volume of $1 \mathrm{~L}$ was made with filtered seawater. The growth medium was autoclaved at $121^{\circ} \mathrm{C}$ at $15 \mathrm{psi}$ for $20 \mathrm{~min}$. The composition (in $\mathrm{mg} \mathrm{L}^{-1}$ ) of $\mathrm{f} / 2$-growth medium was as follows: $\mathrm{NaNO}_{3}-75, \mathrm{NaH}_{2} \mathrm{PO}_{4} \cdot \mathrm{H}_{2} \mathrm{O}-5$, Fe-EDTA-5, $\mathrm{CuSO}_{4} \cdot 5 \mathrm{H}_{2} \mathrm{O}-0.0098$, $\mathrm{ZnSO}_{4} \cdot 7 \mathrm{H}_{2} \mathrm{O}-0.022, \mathrm{CoCl}_{2} \cdot 6 \mathrm{H}_{2} \mathrm{O}-0.010, \mathrm{MnCl}_{2} \cdot 4 \mathrm{H}_{2} \mathrm{O}-0.180, \mathrm{Na}_{2} \mathrm{MoO}_{4} \cdot 2 \mathrm{H}_{2} \mathrm{O}-0.006$, and $\mathrm{pH} 7.9$ [12]. The culture medium after inoculation was incubated at $24 \pm 1{ }^{\circ} \mathrm{C}$ in a growth chamber controlled thermostatically and illuminated using cool fluorescent lamps at a photon flux density of $30 \mu \mathrm{E} \mathrm{m} \mathrm{m}^{-2} \mathrm{~s}^{-1}$ under 12/12 light/dark cycle.

\subsection{Laboratory Screening Studies}

A known quantity $(30 \mathrm{~mL})$ of seed culture of four different isolates of Tetraselmis spp. (Tetraselmis tetrathele, Tetraselmis striata, Tetraselmis chuii, and Tetraselmis gracilis) was inoculated in $500 \mathrm{~mL}$ Erlenmeyer flasks with $270 \mathrm{~mL}$ of sterile $\mathrm{f} / 2$-medium. Lab studies were conducted for a duration of $21 \mathrm{~d}$, and for every $3 \mathrm{~d}$ interval, the growth parameters such as cell numbers, biomass [13], different pigment levels viz. chlorophyll $a$ and $b$, carotenoids [14], total carbohydrates [15], proteins [16], and lipids [17] were recorded. Media optimization studies for the selected algal isolate were conducted using different strengths of $\mathrm{f} / 2$-medium [i.e., full strength ( $\mathrm{f} / 2$-medium), 2 times the concentration of $\mathrm{f} / 2$ (f-medium), 5 times the concentration of $\mathrm{f} / 2$ (5f-medium), and 10 times the concentration of $\mathrm{f} / 2$ (10f-medium)]. A low-cost medium was also developed by optimising the nutrient concentration in the Modified CFTRI medium $\left(\mathrm{mg} \mathrm{L}^{-1}\right)$ with the following composition: Urea-250, Single super phosphate-20, $\mathrm{FeCl}_{3}-4$, $\mathrm{MgSO}_{4}-150, \mathrm{NaHCO}_{3}-150$, Sea water- $1 \mathrm{~L}$, and $\mathrm{pH}$ 8.0. 


\subsection{Molecular Characterisation}

The Dye De-oxy Terminator Cycle Sequencing PCR kit obtained from GENEI, Bangalore, India, was used to isolate the genomic DNA samples of $T$. striata from the lyophilized algal biomass. To eliminate RNA contamination, the extract was digested for $30 \mathrm{~min}$ with $10 \mu \mathrm{g}$ of RNase-A at $37^{\circ} \mathrm{C}$. DNA concentration was determined by a spectrophotometer measuring its absorbance at $260 \mathrm{~nm}$. The isolate of T. striata was subjected for molecular identification in order to ascertain its systematic position. The genomic DNA of the culture was isolated according to Richards et al. [18]. In the present study, the forward primer $5^{\prime}$-GTAACCCGTTGAACCCCATT- $3^{\prime}$ and reverse primer 5'-CCATCCAATCGGTAGTAGCG-3' were used as recommended by Liu et al. [19]. The $18 \mathrm{~S}$ rRNA gene region of T. striata was isolated and subjected to the amplification of primers at GENEI, Bangalore, India. Polymerase chain reaction (PCR) using a PCR program was performed in an ABI thermal cycler (ABI) with initial denaturing at $95^{\circ} \mathrm{C}$ for $5 \mathrm{~min}$, followed by 35 cycles of denaturation at $95{ }^{\circ} \mathrm{C}$ for $1 \mathrm{~min}$, annealing at $58^{\circ}$ for $55 \mathrm{~s}$, extension at $72{ }^{\circ} \mathrm{C}$ for $50 \mathrm{~s}$, and a final extension at $72{ }^{\circ} \mathrm{C}$ for $10 \mathrm{~min}$. The PCR products were separated through agarose gel electrophoresis. The purified PCR products were separated using $1.4 \%$ agarose gels and stained with $0.5 \mu \mathrm{g} \mathrm{mL} \mathrm{L}^{-1}$ ethidium bromide. The gel was viewed and captured using the Vilber Loumart Gel Documentation system. Sequences were determined by the chain termination method with the use of Dye De-oxy Terminator Cycle Sequencing Kit (Perkin Elmer Applied Bio-system, Wokingham, UK) with AV1377 automated DNA sequencer.

\subsection{Acclimatisation of T. striata Butcher BBRR1 for Outdoor Cultivation}

The laboratory grown isolate of T. striata BBRR1 was scaled-up to 1 and $2 \mathrm{~L}$ in conical flasks and further scaled up for 2 weeks to $10 \mathrm{~L}$ in transparent $30 \mathrm{~L}$ carboys for acclimatization under outdoor conditions. The seed culture of $15 \mathrm{~L}$ was inoculated in $135 \mathrm{~L} \mathrm{f} / 2$-medium in a $1.0-\mathrm{m}^{2}$ mini open raceway pond (150 L capacity) coated with fibre-reinforced plastic (FRP) material (length $2.2 \mathrm{~m}$; width $0.50 \mathrm{~m}$; depth $0.26 \mathrm{~m}$ ) and incubated for 2 weeks. The growth medium before inoculation was sterilised by adding $50 \mathrm{ppm}$ of sodium hypochlorite to remove contaminants. After $12 \mathrm{~h}$ treatment, sodium thiosulphate (2.85 mg per $1 \mathrm{mg}$ of chlorine) was added to the growth medium to neutralise the residual chlorine. The raceway pond was agitated with a paddle wheel system at $10 \mathrm{rpm}$. The culture was mixed with the paddle wheel system during daytime only. During the experiment, the evaporated water was compensated with chlorine-treated bore well water (after neutralising residual chlorine with sodium thiosulphate) and the ponds were protected on top from dust with a transparent polythene sheet. Adaptation of the algal culture to outdoor conditions was continued for 2 weeks, and the culture without contamination after 2 weeks of exposure was used as inoculum for mass culture trials. Vit K3 (5 ppm) was added to the growth medium in the open raceway pond to prevent cyanobacterial contamination.

\subsection{Mass Culture of T. striata BBRR1 in 10- $m^{2}$ Open Raceway Pond}

The experiment was conducted in two numbers of 10- $\mathrm{m}^{2}$ FRP-coated concrete raceway ponds of $2000 \mathrm{~L}$ capacity (length $7 \mathrm{~m}$; width $1.5 \mathrm{~m}$; depth $0.26 \mathrm{~m}$ ) each. The order in which the inoculum raised was as follows: $15 \mathrm{~L}$ of optimally grown T. striata BBRR1 culture in the lab with $0.06 \mathrm{~g} \mathrm{~L}^{-1}$ of biomass concentration was inoculated into two numbers of $1-\mathrm{m}^{2}$ raceway ponds each containing $135 \mathrm{~L}$ of $\mathrm{f}$-medium and grown for $10 \mathrm{~d}$. The composition of $\mathrm{f}$ medium (in $\mathrm{mg} \mathrm{L}^{-1}$ ) was as follows: $\mathrm{NaNO}_{3}-150, \mathrm{NaH}_{2} \mathrm{PO}_{4} \cdot \mathrm{H}_{2} \mathrm{O}-10$, Fe-EDTA-10; $\mathrm{CuSO}_{4} \cdot 5 \mathrm{H}_{2} \mathrm{O}-0.0196, \mathrm{ZnSO}_{4} \cdot 7 \mathrm{H}_{2} \mathrm{O}-0.044$, $\mathrm{CoCl}_{2} \cdot 6 \mathrm{H}_{2} \mathrm{O}-0.020, \mathrm{MnCl}_{2} \cdot 4 \mathrm{H}_{2} \mathrm{O}-0.360, \mathrm{Na}_{2} \mathrm{MoO}_{4} \cdot 2 \mathrm{H}_{2} \mathrm{O}-0.012$ and $\mathrm{pH}$ 7.9. Then the culture $(150 \mathrm{~L})$ was inoculated to $10-\mathrm{m}^{2}$ raceway ponds containing (a) $1350 \mathrm{~L}$ of $\mathrm{f}$-medium as control and (b) Modified CFTRI ABRR1 medium as treatment. The composition of Modified CFTRI ABRR1 medium $\left(\mathrm{mg} \mathrm{L}^{-1}\right)$ was as follows: Urea-50, Single super phosphate-40, $\mathrm{FeCl}_{3}-10, \mathrm{MgSO}_{4}-250, \mathrm{NaHCO}_{3}-500$, Sea water-1 L and $\mathrm{pH}$ 8.5. The culture height in the pond was maintained at $15 \mathrm{~cm}$ level with the total volume of $1500 \mathrm{~L}$. The algal culture was mixed using paddle wheels during the daytime to control settling of 
algal cells and to improve dissolved $\mathrm{CO}_{2}$ levels. This experiment was conducted in batch mode for a period of $21 \mathrm{~d}$. The culture purity was monitored on a daily basis, and other parameters such as $\mathrm{pH}$, biomass, pigments, lipids, proteins, and carbohydrates were analysed at every $3 \mathrm{~d}$ interval. Daily temperature and light intensity were also measured.

\subsection{Biomass Harvest of T. striata BBRR1}

Biomass of T. striata BBRR1 was harvested by switching off the paddle wheel for a period of $12 \mathrm{~h}$. The biomass settled at the bottom through auto flocculation was collected after the medium was drained off. To remove the excess salts from the algal biomass, it was washed with acidified water 3 times. The washed algal cells were dried for $3 \mathrm{~h}$ in the sunlight, followed by oven drying for $8 \mathrm{~h}$ at $60^{\circ} \mathrm{C}$.

\subsection{Estimation of Biomass and Other Growth Parameters}

Twenty-five millilitres of algal culture was taken and washed thrice with $25 \mathrm{~mL}$ of isotonic solution containing $0.65 \mathrm{M}$ ammonium formate [13] in order to remove excess salts. Pre-weighed Whatman GF/C glass microfiber filters $(1.2 \mu \mathrm{m})$ were used to obtain the biomass after filtration in the moisture analyser (Mettler Toledo HR83). Then, the filter along with the biomass was placed in the moisture analyser, and its final dry weight was recorded after drying at $100{ }^{\circ} \mathrm{C}$ for $8 \mathrm{~min}$. Dry weight was calculated after subtracting the filter weight, and the dry weight measured was expressed as $\mathrm{g} \mathrm{L}^{-1}$. Following equations were used for the calculation of the growth parameters given below where $\mu\left(\right.$ day $\left.^{-1}\right)$ is the specific growth rate, $N_{1}$ and $N_{2}$ are the biomass at time 1, i.e., $t_{1}$ and time 2 , i.e., $t_{2}$, respectively.

$$
\begin{gathered}
\mu\left(\text { day }^{-1}\right)=\ln \left(\mathrm{N}_{2} / \mathrm{N}_{1}\right) /\left(\mathrm{t}_{2}-\mathrm{t}_{1}\right) \\
\text { Divisions per day }=\mu / \ln 2 \\
\text { Generation time (days) }=1 / \text { Div. day }{ }^{-1}
\end{gathered}
$$

\subsection{Extraction of Algal Oil and Analysis of Fatty Acids}

A known quantity of dried algal biomass $(10 \mathrm{~g})$ was treated using hexane at a ratio of 1:5 $(\mathrm{w} / \mathrm{v})$, and the algal oil was extracted using a Soxhlet apparatus. The solvent extraction process was continued for $8 \mathrm{~h}$. After the extraction, the solvent containing the algal oil was filtered through Whatman GF/C filter paper. The solvent was recovered using a rotary evaporator at the respective boiling temperature. Algal oil obtained after solvent removal was quantified, and the yield was expressed on the basis of ash-free dry biomass.

\subsection{Acid Transesterification}

Ten grams of total lipid extracted from the alga was combined with $0.6 \mathrm{~mL} \mathrm{~g}^{-1}$ of sulphuric acid and a mixture of $4 \mathrm{~mL} \mathrm{~g}^{-1}$ each of chloroform and methanol (2:1), hexane, and petroleum ether. The reaction mixture was kept in a water bath for $40 \mathrm{~min}$ at $90^{\circ} \mathrm{C}$ and was mixed intermittently. Then it was cooled at room temperature followed by the addition of $2 \mathrm{~mL} \mathrm{~g}^{-1}$ of distilled water. This solution was mixed for $45 \mathrm{~s}$. After phase separation, the solvent layer containing biodiesel fatty acid methyl ester (FAME) was collected and transferred to a pre-weighed glass vial. The solvent was then evaporated using liquid $\mathrm{N}_{2}$, and the amount of biodiesel obtained was quantified gravimetrically. FAME was analysed by GC-MS [Agilent 6890 gas chromatograph, $15 \mathrm{~m}$ Alltech EC-5 column (250 $\mu$ I.D., $0.25 \mu$ film thickness)]. A JEOL GCmate II bench top double-focusing magnetic sector mass spectrometer operating in electron ionization (EI) mode with TSS-20001 software was used for all the analyses. Identification of FAME was made by matching their recorded spectra with the databank mass spectra of NIST library V 11 provided by the instrument software. 


\subsection{Statistical Analysis}

Throughout the study period, triplicates were maintained for each experiment. The results were expressed as mean \pm standard deviation. Statistical analysis of the data was done using Origin Pro. V 8.0 for Windows.

\section{Results and Discussion}

\subsection{Isolation of Tetraselmis Spp.}

In the present attempt, from the water samples collected from the saltpans (salinity: $60 \mathrm{ppt}$ ) in Kovelong, Chennai, Tamil Nadu, India, four different isolates were obtained. Based on the colony morphology, colour, and cell size, these isolates were identified as quadriflagellate algae belonging to the genus Tetraselmis. The isolates include Tetraselmis chuii, T. gracilis, T. striata, and T. tetrathele (Figure 1a,b) [12]. Tetraselmis is a euryhaline microalga and commonly present in saltpans and marine environments $[20,21]$. T. chuii Butcher is a green four-flagellated alga having an ovoid body shape with a distinct curve (cell length: 12-14 $\mu \mathrm{m}$, width: 9-10 $\mu \mathrm{m}$ ). T. gracilis (Kylin) Butcher cells are ellipsoid and slightly compressed. The cells showed four anterior lobes, large pyrenoids, sub-basal with U-shaped starch shield, and median eyespot in red-orange colour. The length and width of the cells observed were 8-12 $\mu \mathrm{m}$ and 6-9 $\mu \mathrm{m}$, respectively. T. striata Butcher cells showed longitudinal rows of granules and a posterior eyespot with cell length and width of 10-21 $\mu \mathrm{m}$ and 8-17 $\mu \mathrm{m}$, respectively. T. tetrathele (G.S.West) Butcher cells appeared compressed, with deep and wide four-lobed apical furrows. The cell length and width were 10-16 $\mu \mathrm{m}$ and 8-12 $\mu \mathrm{m}$, respectively. The cells appeared bright green when grown in $\mathrm{f} / 2$-agar medium under $30 \mu \mathrm{E} \mathrm{m}^{-2} \mathrm{~s}^{-1}$ light intensity and 12/12 light/dark cycle at $24 \pm 1^{\circ} \mathrm{C}$. $\mathrm{f} / 2$-medium was reported to be the best growth medium for marine and brackish water strains of algae [13].

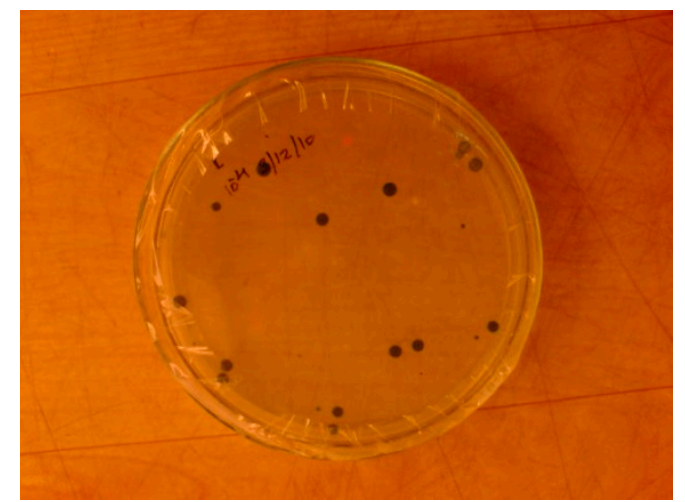

(a)

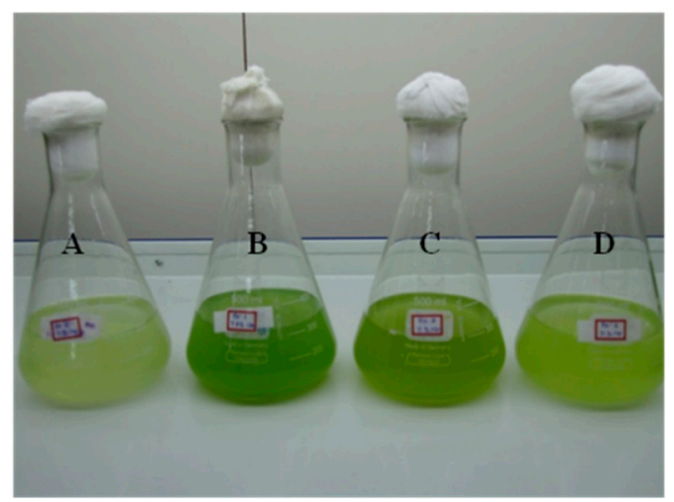

(b)

Figure 1. (a) Colonies of Tetraselmis spp. On $\mathrm{f} / 2$-agar medium on the 20th day. (b) T. tetrathele (A), T. striata (B), T. chuii (C), and T. gracilis (D) after $18 \mathrm{~d}$ of growth.

\subsection{Screening Studies-Dry Biomass and Total Lipids in Tetraselmis spp.}

The four different species of Tetraselmis isolated were screened for their growth performance under laboratory conditions. This study revealed that the isolate of $T$. striata showed the maximum biomass concentration, lipid content and volumetric biomass productivity of $0.58 \pm 0.021 \mathrm{~g} \mathrm{~L}^{-1}, 151 \pm 3 \mathrm{mg} \mathrm{L}^{-1}$, and $0.025 \pm 0.004 \mathrm{~g} \mathrm{~L}^{-1} \mathrm{~d}^{-1}$, respectively (Figure 2a,b; Table 1). Huerlimann et al. [22] reported a maximum biomass concentration of $0.35 \mathrm{~g} \mathrm{~L}^{-1}$ for $T$. gracilis, which was $8 \%$ less than the test alga, T. striata. Arkronrat et al. [23] reported a specific growth rate of 0.16 day $^{-1}$ in Tetraselmis spp., which was $36 \%$ less than the specific growth rate of 0.25 day $^{-1}$ recorded by the test alga T. striata used in this study. In the present study, the isolate of T. striata Butcher had the highest lipid content compared to the other three isolates. T. striata recorded a maximum lipid content of $33.60 \%$ and lipid productivity 
of $7.21 \mathrm{mg} \mathrm{L}^{-1} \mathrm{~d}^{-1}$ (Table 1). Huerlimann et al. [22] reported a lipid productivity of $18.6 \mathrm{mg} \mathrm{L}^{-1} \mathrm{~d}^{-1}$ for Tetraselmis spp., which was 2.6 times more than the lipid productivity recorded by the isolate T. striata used in this study.

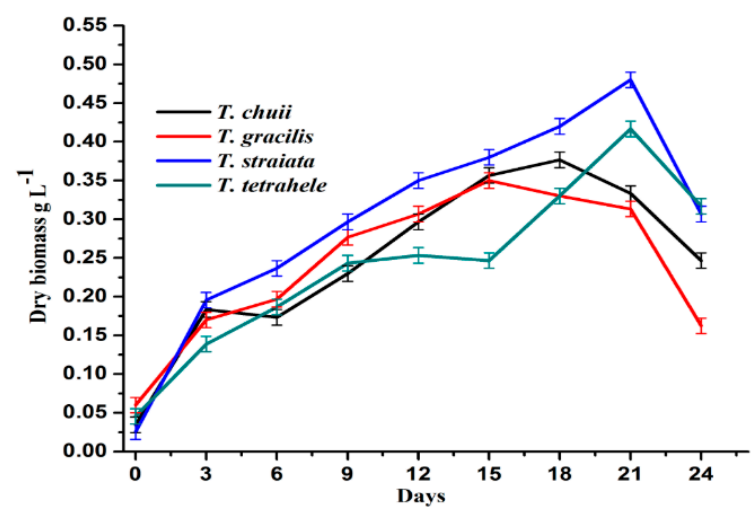

(a)

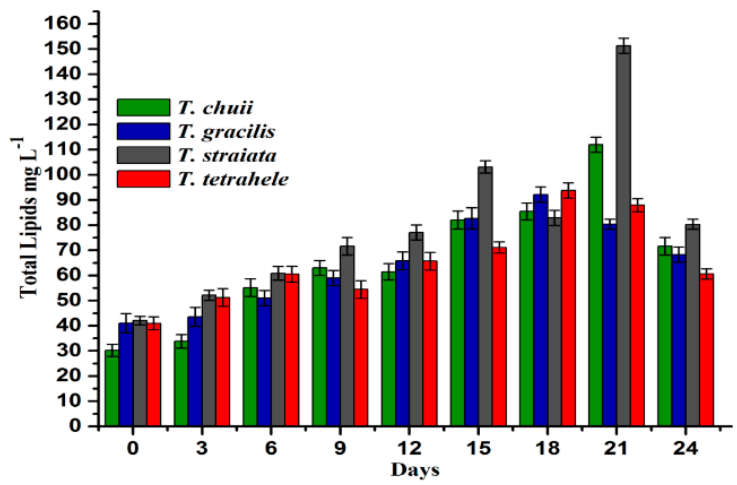

(b)

Figure 2. (a) Dry biomass and (b) total lipids of Tetraselmis spp. At different intervals.

Table 1. Biomass, lipid productivity, lipid content and $\mathrm{CO}_{2}$ utilisation of different Tetraselmis spp.

\begin{tabular}{|c|c|c|c|c|}
\hline Strains & $\begin{array}{c}\text { Volumetric Biomass } \\
\text { Productivity }\left(\mathrm{g} \mathrm{L}^{-1} \mathrm{~d}^{-1}\right)\end{array}$ & $\begin{array}{l}\text { Lipid Productivity } \\
\left(\mathrm{mg} \mathrm{L}^{-1} \mathrm{~d}^{-1}\right)\end{array}$ & Lipid Content (\%) & $\begin{array}{l}\mathrm{CO}_{2} \text { Fixed } \\
\left(\mathrm{g} \mathrm{L}^{-1} \mathrm{~d}^{-1}\right)\end{array}$ \\
\hline T. chuii & $0.023 \pm 0.003$ & $5.33 \pm 0.005$ & $31.46 \pm 1.24$ & $0.042 \pm 0.012$ \\
\hline T. gracilis & $0.024 \pm 0.004$ & $5.12 \pm 0.004$ & $27.88 \pm 1.12$ & $0.042 \pm 0.013$ \\
\hline T. striata & $0.025 \pm 0.004$ & $7.21 \pm 0.005$ & $33.60 \pm 1.25$ & $0.046 \pm 0.025$ \\
\hline T. tetrathele & $0.021 \pm 0.005$ & $5.22 \pm 0.004$ & $28.48 \pm 1.05$ & $0.038 \pm 0.017$ \\
\hline
\end{tabular}

Data represent mean \pm standard Error (SE) of three replicates.

Age, morphology, and quality of the culture could vary depending on the chemical composition of the growth media and growth conditions [24]. The variation observed in the lipid productivity of the Tetraselmis strain used in this study when compared to the values reported in the literature, could be attributed to the above factors. As the isolate T. striata BBRR1 outperformed all other isolates in terms of biomass and lipid productivity, further studies were conducted to assess this isolate for its growth performance in different strengths of $\mathrm{f} / 2$-medium as mentioned below: full strength (f/2-medium), 2 times the concentration of $\mathrm{f} / 2$ (f-medium), 5 times the concentration of $\mathrm{f} / 2$ ( $5 \mathrm{f}$-medium), and 10 times the concentration of $\mathrm{f} / 2$ (10f-medium). Among these, $\mathrm{f}$-medium outperformed all other media for the growth of $T$. straiata in terms of biomass productivity and specific growth rate, in lab studies (Table 2). However, as the cost of this medium was high, a low-cost medium (Modified CFTRI ABRR1) was developed by optimising the concentrations of nutrients present in the Modified CFTRI medium to improve the growth of algae. Though the biomass productivity was less, the Modified CFTRI ABRR1 medium recorded a 58\% increase in the specific growth rate and a 60\% increase in lipid productivity when compared to Modified CFTRI medium under laboratory conditions (Table 3). The costs of $\mathrm{f} / 2$, $\mathrm{f}$, Modified CFTRI and Modified CFTRI ABRR1 media were US\$1.1, 2.2, 0.4, and 0.6 per L, respectively. The cost of Modified CFTRI ABRR1 medium was $45 \%$ cheaper than $\mathrm{f} / 2$-medium and $73 \%$ cheaper than f-medium. 
Table 2. Growth performance of $T$. striata in different strengths of $\mathrm{f} / 2$-medium.

\begin{tabular}{|c|c|c|c|c|}
\hline Growth Media & $\begin{array}{c}\text { Volumetric Biomass } \\
\text { Productivity }\left(\mathrm{g} \mathrm{L}^{-1} \mathrm{~d}^{-1}\right)\end{array}$ & $\begin{array}{l}\text { Specific Growth } \\
\text { Rate }\left(\mathrm{Day}^{-1}\right)\end{array}$ & Div. $d^{-1}$ & Gen' $^{\prime} \mathrm{t}(\mathrm{d})$ \\
\hline $\mathrm{f} / 2(1 \times)$ & $0.022 \pm 0.005$ & $0.39 \pm 0.07$ & $0.56 \pm 0.04$ & $1.79 \pm 0.08$ \\
\hline$f(2 \times)$ & $0.027 \pm 0.004$ & $0.41 \pm 0.06$ & $0.59 \pm 0.03$ & $1.69 \pm 0.05$ \\
\hline $5 f(5 \times)$ & $0.019 \pm 0.006$ & $0.16 \pm 0.03$ & $0.24 \pm 0.07$ & $4.25 \pm 0.03$ \\
\hline $10 f(10 \times)$ & $0.003 \pm 0.003$ & $0.16 \pm 0.04$ & $0.23 \pm 0.05$ & $4.31 \pm 0.05$ \\
\hline
\end{tabular}

Data represent mean \pm standard Error (SE) of three replicates.

Table 3. Growth performance of T. striata in low-cost algal growth media.

\begin{tabular}{cccccc}
\hline $\begin{array}{c}\text { Growth } \\
\text { Medium }\end{array}$ & $\begin{array}{c}\text { Volumetric Biomass } \\
\text { Productivity }\left(\mathbf{g ~ L}^{-\mathbf{1}} \mathbf{d}^{\mathbf{- 1}}\right)\end{array}$ & $\begin{array}{c}\text { Specific Growth } \\
\text { Rate }\left(\mathbf{d a y}^{\mathbf{- 1}}\right)\end{array}$ & Div. d & Gen' $\mathbf{~ ( d ) ~}$ & $\begin{array}{c}\text { Lipid Productivity } \\
\left(\mathbf{m g ~ L}^{-\mathbf{1}} \mathbf{d}^{-\mathbf{1}}\right)\end{array}$ \\
\hline $\begin{array}{c}\text { [A] Modified } \\
\text { CFTRI }\end{array}$ & $0.81 \pm 0.04$ & $0.38 \pm 0.06$ & $0.55 \pm 0.03$ & $1.81 \pm 0.07$ & $8.41 \pm 0.013$ \\
$\begin{array}{c}\text { [B] Modified } \\
\text { CFTRI }\end{array}$ & $0.71 \pm 0.08$ & $0.60 \pm 0.08$ & $0.86 \pm 0.05$ & $1.16 \pm 0.05$ & $13.44 \pm 0.015$ \\
ABRR1 & & & & \\
\hline
\end{tabular}

Data represent mean \pm standard Error (SE) of three replicates.

The morphological parameters may not be enough to identify the strains at species level. Hence, molecular tools like PCR are needed for confirming the systematic position of the algal isolates. In the present study, the $18 \mathrm{~S}$ region of the ribosomal RNA gene was isolated and amplified with the specific primers. The obtained sequence was compared with the existing sequences in the NCBI database by the BLAST algorithm homology (sequence identity). This sequence was found to have $99 \%$ similarity with T. striata JQ315813 KMMCC 1157 strain in the database. Based on the classical taxonomy as well as molecular taxonomy, the test alga was identified and confirmed as T. striata Butcher BBRR1 (Figure 3). The sequence was submitted to the GenBank, NCBI, and the accession number (KP317837) was obtained.

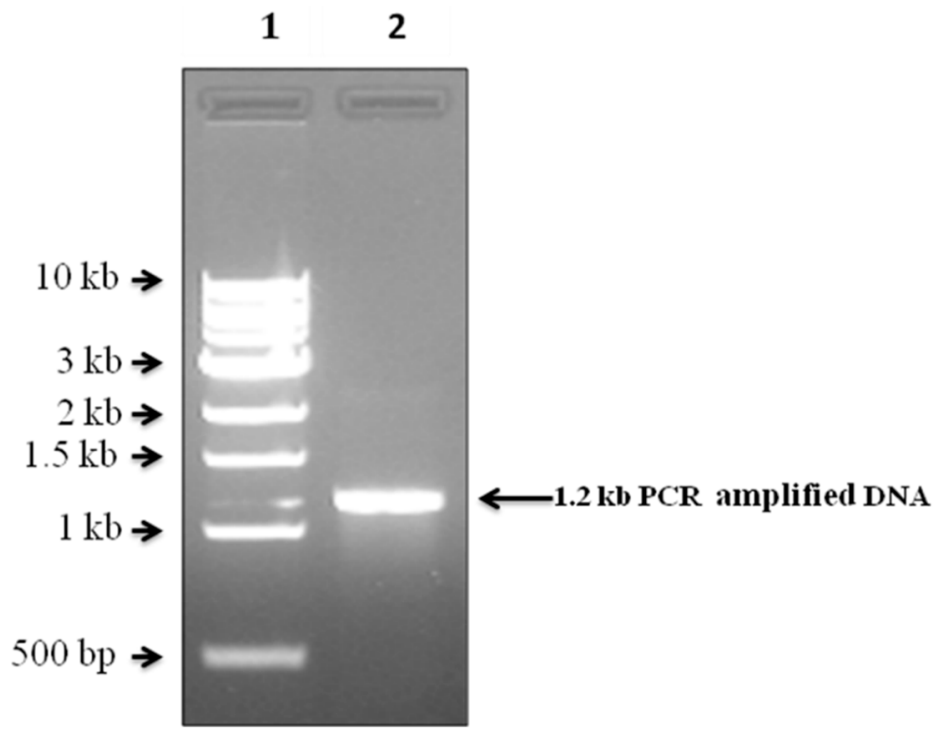

Figure 3. PCR amplification of $18 \mathrm{~S}$ rRNA gene of T. striata. Lane 1. DNA ladder (kB); Lane 2. PCR amplified product of $T$. striata.

\subsection{Growth Performance of T. striata BBRR1 in 10- $m^{2}$ Open Raceway Ponds}

A trial was conducted to compare the growth performance T. striata BBRR1 in f-medium (control) and Modified CFTRI ABRR1 medium (treatment) cultivated in 10- $\mathrm{m}^{2}$ open raceway ponds. The alga recorded volumetric chlorophyll $a$ productivities of $0.394 \mathrm{mg} \mathrm{L}^{-1} \mathrm{~d}^{-1}$ and $0.335 \mathrm{mg} \mathrm{L}^{-1} \mathrm{~d}^{-1}$ in the 
treatment and control, respectively on day 15 (Figure 4a). Volumetric productivity of chl $a$ in the treatment recorded an $18 \%$ increase when compared to the control. The alga grown in the treatment showed an $8.4 \%$ increase in volumetric productivity of chl $b$ over control on day 18 (Figure $4 \mathrm{~b}$ ). Volumetric productivity of carotenoids recorded a 5\% increase for the treatment over control on day 18 (Figure 4c).

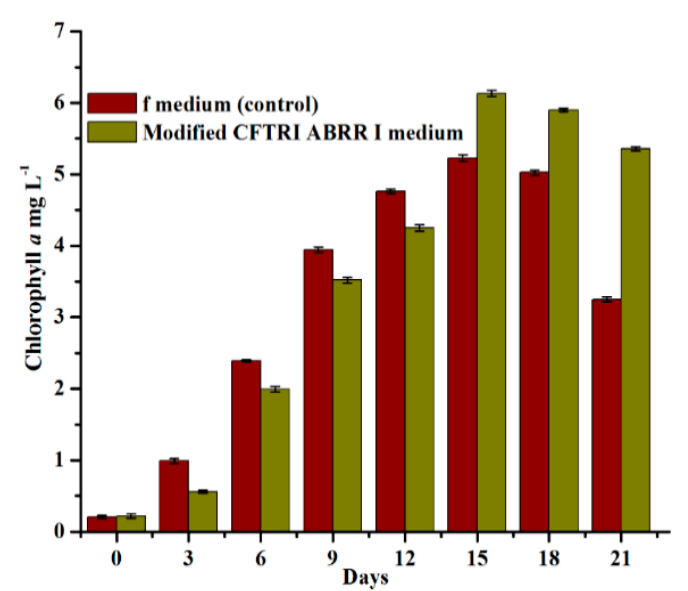

(a)

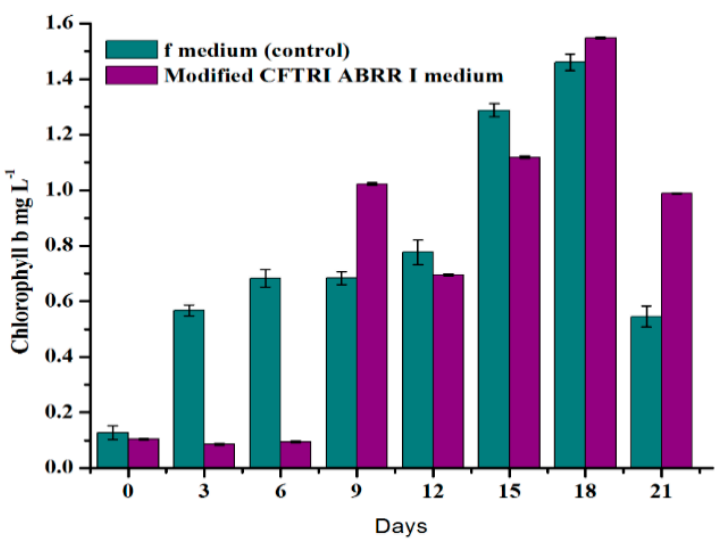

(b)

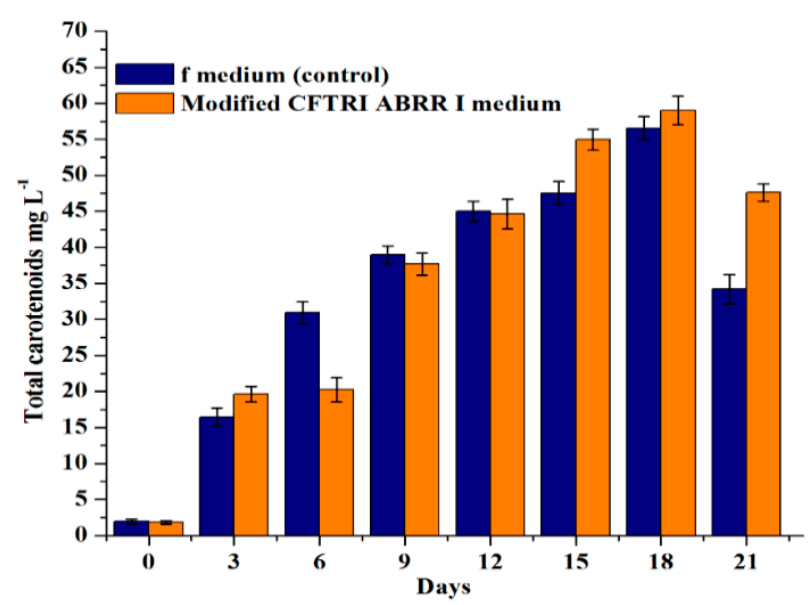

(c)

Figure 4. (a) Chlorophyll $a$, (b) chlorophyll $b$, and (c) total carotenoids of T. striata BBRR1 in Modified CFTRI ABRR1 medium at different intervals in 10- $\mathrm{m}^{2}$ open raceway pond.

The observations in the present study clearly indicated that the cells continued their growth that resulted in the net increase of biomass up to day $15 \mathrm{in} \mathrm{both} \mathrm{control} \mathrm{and} \mathrm{treatment.} \mathrm{In} \mathrm{the} \mathrm{treatment,}$ the initial biomass of $0.12 \pm 0.01 \mathrm{~g} \mathrm{~L}^{-1}$ increased up to a maximum of $0.95 \pm 0.06 \mathrm{~g} \mathrm{~L}^{-1}$ on the 15th day, which was $28 \%$ higher than that of the control (Figure 5). T. Striata BBRR1 cultivated in the open raceway pond using Modified CFTRI ABRR1 medium (treatment) recorded 47, 15, 15, and 16\% increases in the specific growth rate, volumetric biomass productivity, areal biomass productivity, and lipid productivity over control (f-medium), respectively (Table 4). 


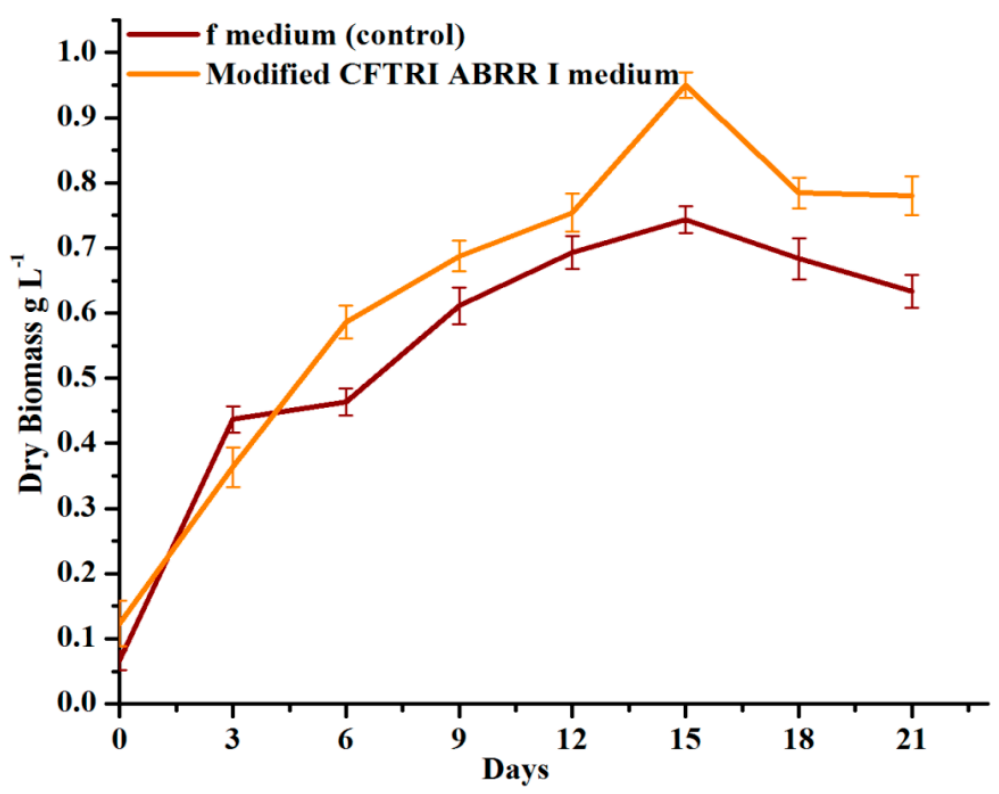

Figure 5. Dry biomass production by T. striata BBRR1 in f-medium and Modified CFTRI ABRR1 medium at different time intervals in $10-\mathrm{m}^{2}$ open raceway ponds.

Table 4. Growth performance of T. striata BBRR1 cultivated under lab and outdoor conditions in different media.

\begin{tabular}{|c|c|c|c|c|c|c|c|}
\hline S.No & Culture Conditions & $\begin{array}{c}\text { Specific } \\
\text { Growth } \\
\text { Rate } \\
\left(\text { Day }^{-1}\right)\end{array}$ & Div. $d^{-1}$ & Gen' t (d) & $\begin{array}{l}\text { Volumetric } \\
\text { Biomass } \\
\text { Productivity } \\
\left(\mathrm{g} \mathrm{L}^{-1} \mathrm{~d}^{-1}\right)\end{array}$ & $\begin{array}{l}\text { Areal } \\
\text { Biomass } \\
\text { Productivity } \\
\left(\mathrm{g} \mathrm{m}^{-2} \mathrm{~d}^{-1}\right)\end{array}$ & $\begin{array}{c}\text { Lipid } \\
\text { Content (\%) }\end{array}$ \\
\hline 1 & $\begin{array}{l}\text { f/2-medium under } \\
\text { in-vitro study }\end{array}$ & $0.39 \pm 0.07$ & $0.56 \pm 0.04$ & $1.79 \pm 0.08$ & $0.022 \pm 0.02$ & - & $25.07 \pm 0.24$ \\
\hline 2 & $\begin{array}{l}\text { f-medium under } \\
\text { in-vitro study }\end{array}$ & $0.41 \pm 0.06$ & $0.59 \pm 0.03$ & $1.68 \pm 0.08$ & $0.027 \pm 0.05$ & - & $19.42 \pm 0.80$ \\
\hline 3 & $\begin{array}{l}\text { Modified CFTRI } \\
\text { ABRR1 medium } \\
\text { under in-vitro study }\end{array}$ & $0.60 \pm 0.08$ & $0.86 \pm 0.05$ & $1.16 \pm 0.05$ & $0.032 \pm 0.04$ & - & $18.76 \pm 1.30$ \\
\hline 4 & $\begin{array}{l}10-\mathrm{m}^{2} \text { open race way } \\
\text { pond f-medium }\end{array}$ & $0.24 \pm 0.06$ & $0.35 \pm 0.03$ & $2.88 \pm 0.04$ & $0.055 \pm 0.05$ & $8.25 \pm 0.06$ & $16.50 \pm 1.42$ \\
\hline 5 & $\begin{array}{c}\text { 10- } \mathrm{m}^{2} \text { open race way } \\
\text { Modified CFTRI } \\
\text { ABRR1medium }\end{array}$ & $0.45 \pm 0.07$ & $0.64 \pm 0.05$ & $1.55 \pm 0.07$ & $0.063 \pm 0.08$ & $9.45 \pm 0.09$ & $19.42 \pm 0.98$ \\
\hline
\end{tabular}

Data represent mean \pm standard Error (SE) of three replicates.

The alga grown in Modified CFTRI ABRR1 medium under laboratory conditions recorded $54 \%$ and $46 \%$ increases in specific growth rate and $45 \%$ and $19 \%$ increases in volumetric biomass productivity when compared to the alga grown in $\mathrm{f} / 2$ and $\mathrm{f}$-medium, respectively (Table 4 ). The isolate $\mathrm{T}$. striata BBRR1 used in this study recorded an areal biomass productivity of $9.45 \mathrm{~g} \mathrm{~m}^{-2} \mathrm{~d}^{-1}$ in Modified CFTRI ABRR1 medium and $8.25 \mathrm{~g} \mathrm{~m}^{-2} \mathrm{~d}^{-1}$ in f-medium. Fon-Sing and Borowitzka [25] reported an average biomass productivity of $8.3 \mathrm{~g} \mathrm{~m}^{-2} \mathrm{~d}^{-1}$ for Tetraselmis spp. Used in their study.

The lipid content of the alga varied from $16.5 \%$ to $25 \%$, and the average lipid content in all the treatments was $19.8 \%$ (Table 4). Tetraselmis and Nannochloropsis spp. showed high lipid productivity in the experiments conducted by Rodolfi et al. [10], and they reported that these two species of marine algal strains were potential feedstocks for biomass and lipid production.

Nutrient management could change biochemical constituents of algae (Hsieh and $\mathrm{Wu}$ [26]). During the study period, the lipid content in T. striata BBRR1 increased due to growth-limiting factors like nitrogen and phosphorus. Pernet et al. [27], Li et al. [28], and Arumugam et al. [29] also reported 
that the biomass and lipid content of microalgae were affected by cultivation conditions and nutrient composition of growth medium. The culture in the open raceway pond was periodically monitored under microscope, and at the end of the study, the algal biomass in the pond was harvested and dried. The comparative analysis of biomass indicated 27,24 , and $47 \%$ increases in lipids, carbohydrates, and proteins obtained from the outdoor study when compared to the biomass obtained from the lab studies. Regan [30] observed that the total content of lipids varied from $1-85 \%$ of the dry weight in algae, with values higher than $40 \%$ being typically reached under nutrient limitation conditions.

The fatty acid composition of hexane-extracted FAMEs was analysed by GC-MS in the present study. The isolate T. striata BBRR1 recorded the presence of $33.14 \%$ of palmitic acid, followed by $22.64 \%$ 11-octadecenoic acid, 21.94\% heptadecanoic acid, 5.94\% palmitoleicacid, and 3.14\% pentadecanoic acid (Table 5). Similarly, Sharminet al. [9] found significant amounts of myristic acid (C 14:0), palmitic acid (C 16:0), stearic acid (C 18:0), and palmitoleic acid (C 16:1) in the marine microalga Skeletonema costatum isolated from the Bangladesh coast, and they suggested that this algae can be used as biodiesel feedstock.

Table 5. Lipid profile of T. striata BBRR1 grown in the open raceway pond.

\begin{tabular}{cc}
\hline Fatty Acids & Wt. (\%) \\
\hline 7-Octadecene & 1.49 \\
Methyltetradecanoate & 2.63 \\
Pentadecanoic acid, methyl ester & 3.14 \\
Palmitoleic acid, methyl ester & 5.94 \\
Palmitic acid, methyl ester & 33.14 \\
Hexadecanoic acid, 14-methyl-, methyl ester & 2.82 \\
11-Octadecenoic acid, methyl ester & 22.64 \\
Heptadecanoic acid, 16-methyl-, methyl ester & 21.94 \\
Cyclopropane octanoic acid 2-hexyl-methyl ester & 1.64 \\
\hline
\end{tabular}

The areal biomass productivity of T. striata BBRR1 cultivated using Modified CFTRI ABRR1 medium in the $10-\mathrm{m}^{2}$ open raceway pond was $9.45 \mathrm{~g} \mathrm{~m}^{-2} \mathrm{~d}^{-1}$. Based on this areal productivity observed in T. striata BBRR1, it can be concluded that this alga has the potential to produce about 31 dry tons of algal biomass ha ${ }^{-1}$ year ${ }^{-1}$ and can capture and fix 62 tons of $\mathrm{CO}_{2} \mathrm{ha}^{-1}$ year ${ }^{-1}$. Cultivation of algae for biomass production is gaining importance day by day as this biomass can be used for the production of biofuels. However, production cost of algal biomass needs to be reduced below $\$ 150$ per dry ton to make the biofuel production technology from algae economically viable. Currently, the production cost of algal biomass is much higher when compared to that of the biomass resources obtained from terrestrial crops. Marine algae have the potential to produce low-cost feedstock for the production of biofuels in the future. However, more research is required to improve the biomass and lipid productivity of algae in order to reduce the cost of production of biomass and algae biofuels.

\section{Conclusions}

This study envisaged researching the feasibility and sustainability of marine microalgae as biofuel feedstock to meet the energy crisis in the future. In the present attempt, four different marine algal species of Tetraselmis viz. T. chuii Butcher, T. gracilis (Kylin) Butcher, T. striata Butcher, and T. tetrathele (G.S.West) Bucher were isolated and screened for their growth performance. Among these isolates, T. striata recorded the maximum biomass productivity under lab conditions. This strain was further tested in $10-\mathrm{m}^{2}$ open race way pond for biomass and lipid productivity using a low-cost medium under outdoor conditions. This study was the first attempt to cultivate the strain of T. striata BBRR1in an open outdoor raceway pond for biomass and biofuel applications. 
Author Contributions: A.B.B., M.G.R., and R.R. conceived the project and designed the experiments. N.M., S.C., and S.N. assisted in writing the paper. T.J., M.M., and R.R. wrote the paper. J.-R.S. and C.-C.C. contributed clarifications and guidance on the manuscript. All authors were involved in editing the manuscript. All authors have read and agreed to the published version of the manuscript.

Funding: This work was funded by the Ministry of Science and Technology of Taiwan (MOST 104-2622-B-038-003, MOST 104-2320-B-038-045-MY2, MOST 106-2320-B-038-012, MOST 107-2320-B-038-035-MY2) and Taipei Medical University (DP2-108-21121-01-N-02-03) and the APC was funded by MOST.

Acknowledgments: The authors A.B.B. and M.G.R. are thankful to the Biotechnology Division of Aban Group, Chennai, Tamil Nadu, India, for permitting us to use their algae pilot plant facility to conduct our research and providing financial support.

Conflicts of Interest: The authors declare no conflict of interest.

\section{References}

1. Miao, X.; Wu, Q. High yield bio-oil production from fast pyrolysis by metabolic controlling of Chlorella protothecoides. J. Biotechnol. 2004, 110, 85-93. [CrossRef] [PubMed]

2. Raja, A.; Vipin, C.; Aiyappan, A. Biological importance of marine algae an overview. Int. J. Curr. Microbiol. App. Sci. 2013, 2, 222-227.

3. Borowitzka, M.A. High-value products from microalgae-Their development and commercialisation. J. Appl. Phycol. 2013, 25, 743-756. [CrossRef]

4. Nigam, P.S.; Singh, A. Production of liquid biofuels from renewable resources. Prog. Energy Combust. Sci. 2011, 37, 52-68. [CrossRef]

5. Moheimani, N.R.; Mark, P.; McHenry, K.; de Boer, K.; Parisa, B. Biomass and Biofuels from Microalgae: Advances in Engineering and Biology; Springer: Cham, Germany, 2015.

6. Florentinus, A.; Hamelinck, C.; Lint, S.D.; Iersel, S.V. Worldwide Potential of Aquatic Biomass; Ecofys: Utrecht, The Netherlands, 2008.

7. Chisti, Y. Biodiesel from microalgae. Biotechnol. Adv. 2007, 25, 294-306. [CrossRef] [PubMed]

8. Sharmin, T.; Hasan, M.; Md, C.; Aftabuddin, S.; Rahman, M.A.; Khan, M. Growth, Fatty Acid, and Lipid Composition of Marine Microalgae Skeletonemacostatum Available in Bangladesh Coast: Consideration as Biodiesel Feedstock. J. Mar. Biol. 2016, 8, 33-51.

9. Griffiths, M.J.; Harrison, S.T. Lipid productivity as a key characteristic for choosing algal species for biodiesel production. J. Appl. Phycol. 2009, 21, 493-507. [CrossRef]

10. Rodolfi, L.; ChiniZittelli, G.; Bassi, N.; Padovani, G.; Biondi, N.; Bonini, G.; Tredici, M.R. Microalgae for oil: Strain selection, induction of lipid synthesis and outdoor mass cultivation in a low-cost photobioreactor. Biotechnol. Bioeng. 2009, 102, 100-112. [CrossRef]

11. Iyengar, M.O.P.; Desikachary, T.V. Volvocales; Indian Council of Agricultural Research: New Delhi, India, 1981.

12. Guillard, R.R.L.; Ryther, J.H. Studies of marine planktonic diatoms. I. Cyclotella nanaHustedt and DetonulaconfervaceaCleve. Can. J. Microbiol. 1962, 8, 229-239. [CrossRef]

13. Moheimani, N.R. The Culture of Coccolithophore Algae for Carbon Dioxide Bioremediation. Ph.D. Thesis, Murdoch University, Perth, Australia, 2005.

14. Lichtenthaler, H.K. Chlorophylls and carotenoids: Pigments of photosynthetic membranes. Method Enzymol. 1987, 148, 350-382.

15. Dubois, M.; Gilles, K.A.; Hamilton, J.K.; Rebers, P.A.; Smith, F. Colorimetric method for determination of sugars and related substances. Anal. Chem. 1956, 28, 350-356. [CrossRef]

16. Lowry, O.H.; Rosebrough, N.S.; Farrand, A.L.; Randall, R.J. Protein measurement with folin phenol reagent. J. Biol. Chem. 1951, 193, 263-275.

17. Folch, J.; Lees, M.; Sloane, S.G.H. Asimplemethodfortheisolationand purificationof thetotallipids fromanimaltissues. J. Biol. Chem. 1957, 226, 49-57.

18. Richards, E.; Reichardt, M.; Rogers, S. Preparation of genomic DNA from plant tissue. Curr. Prot. Mol. Biol. 1994, 27, 2-3. [CrossRef]

19. Liu, K.H.; Yeh, Y.L.; Shen, W.C. Fast preparation of fungal DNA for PCR screening. J. Microbiol. Meth. 2011, 85, 170-172. [CrossRef]

20. Kawabata, Y.; Nakahara, H.; Katayama, Y.; Ishida, N. The phytoplankton of some saline lakes in Central Asia. Int. J. Salt Lake Res. 1997, 6, 5-16. [CrossRef] 
21. López-González, P.J.; Guerrero, F.; Carmen, C.M. Seasonal fluctuations in the plankton community in a hypersaline temporary lake (Honda, southern Spain). Inter. J. Salt Lake Res. 1998, 6, 353-371. [CrossRef]

22. Huerlimann, R.; De Nys, R.; Heimann, K. Growth, lipid content, productivity, and fatty acid composition of tropical microalgae for scale-up production. Biotechnol. Bioeng. 2010, 107, 245-257. [CrossRef]

23. Arkronrat, W.; Deemark, P.; Oniam, V. Growth performance and proximate composition of mixed cultures of marine microalgae (Nannochloropsis sp. and Tetraselmis sp.) with monocultures. Songklanakarin. J. Sci. Technol. 2016, 38, 326-345.

24. Metzger, P.; Largeau, C. Botryococcusbraunii: A rich source for hydrocarbons and related ether lipids. Appl. Microbiol. Biotechnol. 2005, 66, 486-496. [CrossRef]

25. Fon-Sing, S.; Borowitzka, M.A. Isolation and screening of euryhaline Tetraselmis spp. Suitable for large-scale outdoor culture in hypersaline media for biofuels. J. Appl. Phycol. 2015, 28, 1-14. [CrossRef]

26. Hsieh, C.H.; Wu, W.T. Cultivation of microalgae for oil production with a cultivation strategy of urea limitation. Bioresour. Technol. 2009, 100, 3921-3926. [CrossRef] [PubMed]

27. Pernet, F.; Tremblay, R.; Demers, E.; Roussy, M. Variation of lipid class and fatty acid composition of Chaetocerosmuelleri and Isochrysis sp. grown in a semicontinuous system. Aquaculture 2003, 221, 393-406. [CrossRef]

28. Li, Q.; Du, W.; Liu, D. Perspectives of microbial oils for biodiesel production. Appl. Microbiol. Biotechnol. 2008, 80, 749-756. [CrossRef]

29. Arumugam, M.; Agarwal, A.; Arya, M.C.; Zakwan, A. Influence of nitrogen sources on biomass productivity of microalgae Scenedesmusbijugatus. Bioresour. Technol. 2013, 131, 246-249. [CrossRef] [PubMed]

30. Regan, D.L. Other micro-algae. In Micro-Algal Biotechnology; Borowitzka, M.A., Borowitzka, L.J., Eds.; Cambridge University Press: Cambridge, UK, 1988; pp. 135-150.

(C) 2020 by the authors. Licensee MDPI, Basel, Switzerland. This article is an open access article distributed under the terms and conditions of the Creative Commons Attribution (CC BY) license (http://creativecommons.org/licenses/by/4.0/). 